\title{
Seizing the Means of Domesticity: Mass-Housing Spaces, Objects and Relationships in Soviet Everyday Life
}

\author{
By Steven Shuttle
}

\begin{abstract}
The Soviet state created mass-housing to reshape the city and everyday life itself. This paper examines the spaces and objects of mass-housing to examine the relationship between residents, the state and objects within Soviet everyday life. Approaching the study of everyday life in the Soviet Union from the early 1920s to the late 1980s via the spaces of mass-housing can offer a tangible approach to a way of life that might otherwise seem strange or uncanny. This paper uses ethnographic analysis by drawing on scholarly sources along with five historical photographs. The mass housing spaces of the kommunalka and later khrushchyovka served as places of push and pull. The state attempted to expand the public realm while residents simultaneously tried to create privacy and individuality. Within the interior, the Red Corner and the commode were embodiments of contradictions between modernization and tradition. Despite the state's efforts, commodity fetishism lingered at the core of everyday life. Within Soviet everyday life, mass-housing spaces and objects can be useful to illustrate the changing yet stagnant relationship between residents and the state.
\end{abstract}

\section{Introduction}

Looking back from a contemporary western capitalist consumerist perspective to everyday life in Soviet Russia can bring to mind a certain strangeness of grey and drab apartment blocks. However, some of the most concrete and unique aspects of everyday Soviet life are found within these spaces and objects of mass-housing. Soviet mass-housing consisted of the kommunalka apartments from the 1920 s and beginning in the 1960s expanded to include khrushchyovka apartments. This paper will use an ethnographic approach by combining scholarly sources of Soviet masshousing life with historical photographs. The objects to be examined are the Red Corner and the commode. This paper will explore the contradictions of everyday life in Soviet mass-housing through looking at the spaces and objects, relationships between residents, the state and objects.

\section{Concepts of Everyday life and Soviet Mass-housing}

After the 1917 October Revolution, the early Soviet state continued its revolutionary approach by creating a new form of everyday life. Russian concepts related to this new everyday life are byt, uiut and meshchanstavo. The Soviets' focused on byt or ideas of existence, domesticity and everyday life (Buchli, 1999). In addition to byt, the Soviets translated the concept of viut or coziness, hygiene and comfort from otherwise outdated and pre-revolution ideas (Buchli, 1999). The state's new socialist byt and viut meant reshaping material culture to meet the needs and ideals of the Soviets. In this process, there were efforts to avoid meshchanstavo or a petit-bourgeois lifestyle which were considered distasteful and incompatible with new Soviet 
byt (Varga-Harris, 2015). The desires for revolutionary byt, uiut and meshchanstavo meant the Soviets "would need to be 'antihome'" (Buck-Morss, 2000, p. 192). In this new approach to byt there would be new massinghousing and material culture but no homes.

\section{Kommunalka Spaces and Objects}

Kommunalkas or communal apartments were developed by the Soviets to achieve a new byt and forms of mass-housing. Creating kommunalkas involved reconfiguring existing space to reduce any remaining separation between public and private life. The kommunalkas were made by seizing private homes and putting them under state control and collective ownership. This resulted in reconfiguring singlefamily apartments into smaller, partitioned and hardly private spaces with residents sharing communal kitchens and bathrooms. The state's idea of byt meant that residents were "not entitled to a room or private space but only to a number of square meters" (Boym, 1994, p. 123). The new Soviet kommunalka space blurred the lines between the individual and the communal, with partitions physically restricting the residents' byt and relationships. Residents mostly accepted the overcrowded conditions due to a severe housing shortage (Fitzpatrick, 1999). Coincidentally, the state was provided with an opportunity for mass surveillance within the kommunalkas through residents keeping track of each other. Any sense of privacy within the partitions was "to be subsumed into the public (political) sphere" (Sanatcose, 2014, p. 14) and under the surveillance of other residents and the state. Walter Benjamin, as a Westerner visiting Moscow in 1926, witnessed the strangeness of the Soviet kommunalka firsthand. Benjamin (1986) observed kommunalka "rooms which look[ed] like infirmaries after inspection" (p. 26) which he believed was because "[residents'] way of life has so alienated them from domestic existence" (p. 26). His ethnographic observations reflect the Soviets' efforts at reshaping byt and viut through hygienic interiors. Benjamin also captures the kommunalkas as quasi-public spaces that lack places for private lives. Over a fairly short period of time, the kommunalkas restructured the interior spaces and lives of their residents.

\section{The Red Corner}

The Red Corner was a focus of the early Soviets' modernization of byt through the interior. Historically, the kransnyi ugol or Red Corner comes from the Russian Orthodox tradition of placing religious icons in the most well-lit and best corner of the home (Buchli, 1999). Initially, the Red Corner was appropriated to become ugolok diadi lenina or Uncle Lenin's Corner, a space aimed at teaching children to be good communists (Buchli, 1999). The Red Corner's traditional icons were replaced with new Soviet icons showing "Lenin and pre-revolution suffering" (Buchli, 1999, p. 43). This spatial context gives old quasi-religious meanings to the new Soviet icons. The Red Corner's icons expanded to include Soviet objects "from the family's home republic, maps of USSR, as well as flora and fauna" (Buchli, 1999, p. 43). The Red Corner's maps and plants provided a way for residents to connect with the physical vastness of the Soviet state. This might also diminish any negative feelings of being disconnected from nature and rural hometowns experienced by kommunalka residents in otherwise crowded urban life. Figure 1 shows a Red Corner and the apartment's most important space with modern Soviet photographs. The residents of the apartment in Figure 1 are stakonovites or workers recognized by the Soviets as ideal and exemplary (Fitzpatrick, 1999). This interior space in Figure 1 was believed to reflect and enhance a worker's character as being as clean and cultured. Everyday objects placed in the Red Corner took on charged meanings that pushed towards a modern Soviet byt.

\section{The Commode}

The early Soviets' modernization of byt and attack on petit-bourgeois meshchanstavo focused on the commode. A commode is a type of wooden furniture often "elaborately carved" as seen in Figure 2 and could include "glassed in 


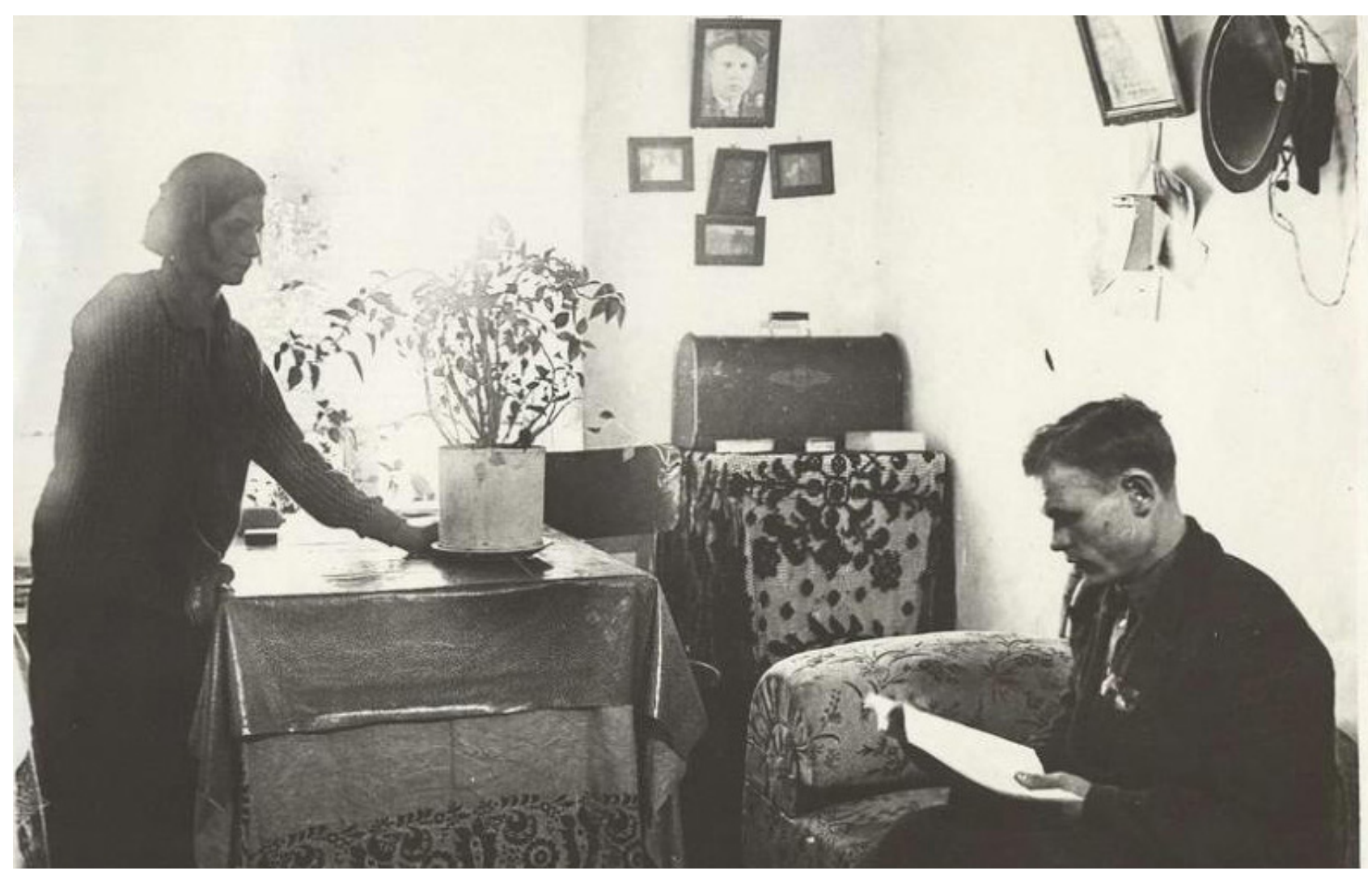

FIGURE 1 Stakonovites with Red Corner in apartment (1939). Retrieved from https://187011.selcdn.ru/ thumbnails/photos/w/7/e/w7e52b33118a59d7_1024.jpg

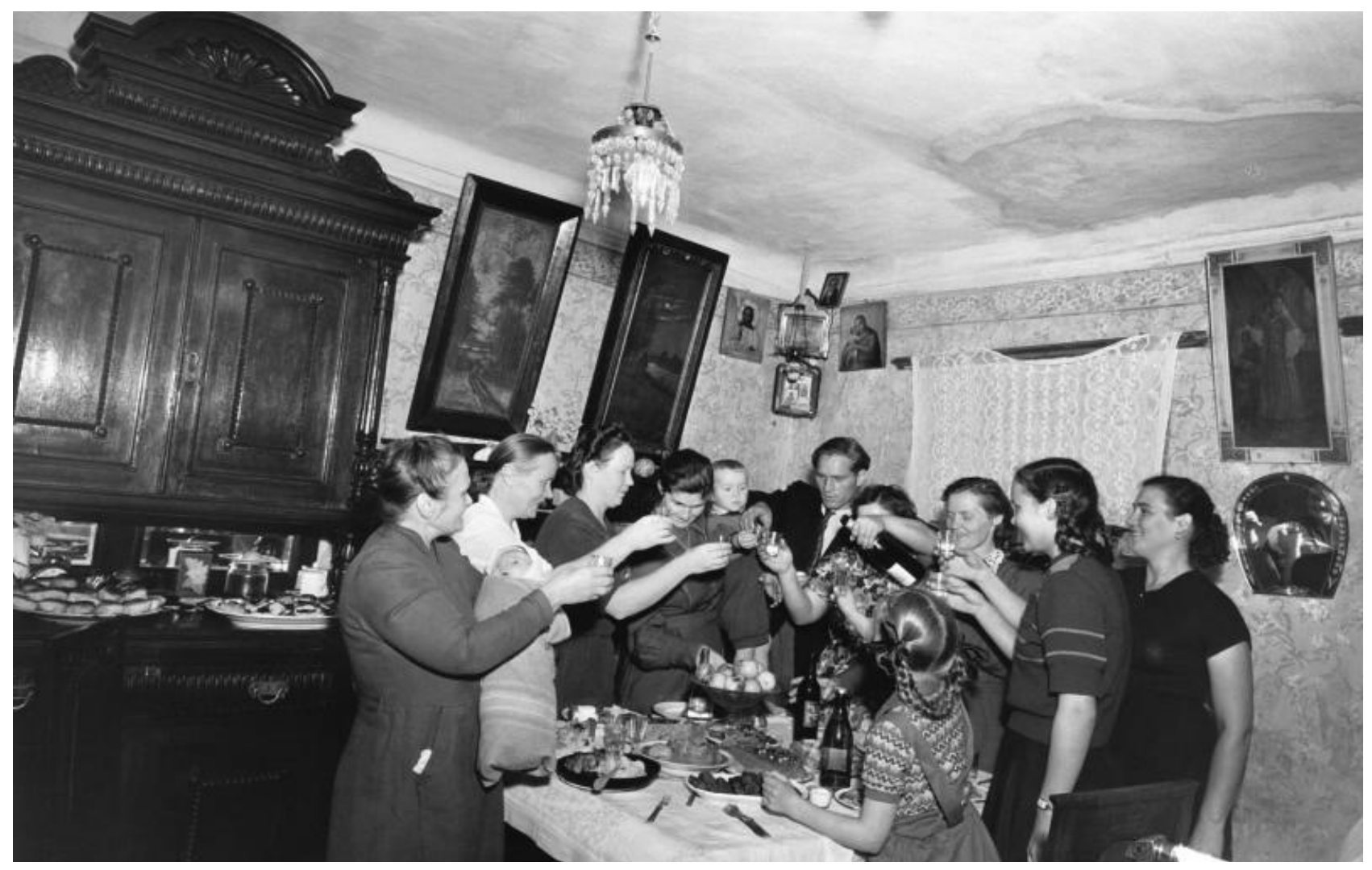

FIGURE 2 The commode and Red Corner at a New Year's apartment party (1947). Savin, M. Retrieved from https://187011.selcdn.ru/thumbnails/photos/8/I/v/8lv52b30d9aa2884_1024.jpg 
shelves" (Buchli, 1999, p. 88), as seen in figures 3,4 and 5, to display a resident's status and prestige objects. Commodes were considered petit-bourgeois by the Soviet state "who actively strove to eradicate" (Buchli, 1999, p. 88) them along with other traces of meshchanstavo from the interior. Despite the state's attempts at getting rid of commodes, they became the location "where the most precious items were kept" (Boym, 1994, p. 151) by residents. The commodes were vital private spaces and often overshadowed the Red Corner both symbolically and literally. Commodes reduced the interior's uiut by taking away from the sense of cleanliness and adding stuffiness (Buchli, 1999). Figure 2 shows a large commode towering over the apartment that diminishes the Red Corner in comparison. The sense of individuality expressed by commodes and their contents could have drawbacks for residents. During the 1930s Great Purges, objects such as commodes were used as evidence of a resident's hidden bourgeoisie status when unmasked as being 'class enemies' or denounced by other residents (Fitzpatrick, 1999). The commode was favored by residents because it allowed them to express their individuality and privacy while circumventing the state-controlled Red Corner.

\section{Kommunalka Residents' Relationships with the State and Objects}

Kommunalka residents may have experienced contradictory or even opposing relationships with the state over visions for byt. A point of contention was the individuality expressed through possession of objects in the communal interior. The state considered private homes to have been abolished once housing was put under communal possession and "leased it out to individuals" (Buchli, 2000, p. 97) to be occupied. Despite this attempt, residents often viewed these kommunalkas as theirs and therefore private space. Another interesting aspect of the relationship is how residents lived in Soviet ideology. Ideally, the kommunalka and its material culture would be "a dialectical complement to the Soviet ideology" (Santacose, 2014, p. 8). The state expressed this by transforming the
Red Corner through removing the Orthodox icons and attacking the use of commodes. However, for kommunalka residents the space became "deideologized in the sense that the contradictions of the system were experienced with no covering gloss" (Buck-Morss, 2000, p.199). The tensions between possession and ideology of space created mixed relationships between residents and the Soviet state.

Residents may have sought relationships with objects, due to the emphasis of material culture on byt. For furniture, most residents preferred "moderne or Neo-Baroque to a Rodchenko or Tatlin [design]" (Bowlt, 1980, p. 145). This attachment and fondness for petitbourgeois objects and designs might have been an attempt to hold onto individuality. In contrast to the unpredictable and shifting public sphere, objects could provide residents with positive feelings and a sense of control or something to desire. Bowlt (1980) points out this kind of relationship between residents and petit-bourgeois objects as the focus of Ilf and Petov's 1928 satirical novel The Twelve Chairs. Residents were attracted towards petit-bourgeois objects as a way of showing individuality.

\section{Soviet Mass-Housing and Commodity Fetishism}

Commodity fetishism was interwoven into the residents' relationships with Soviet objects. Figure 3 shows a Stalinist interior furnished in a petit-bourgeois style, complete with an elaborate commode. The abundance of objects shown in figure 3 would not be a reality for most working residents but only the Soviet elites. However, the interior shown in this picture would be in commodity fetishized dreams of mass-housing residents. Marx's discussion of commodity fetishism uses the table as a vivid metaphor (1979). Marx (1979) exclaims the table's commodity fetishism "evolves out of its wooden brain grotesque ideas" (p. 320). Looking within the kommunalka, another strange and fetishized commodity related to Marx's table might be found hiding in the form of plywood 


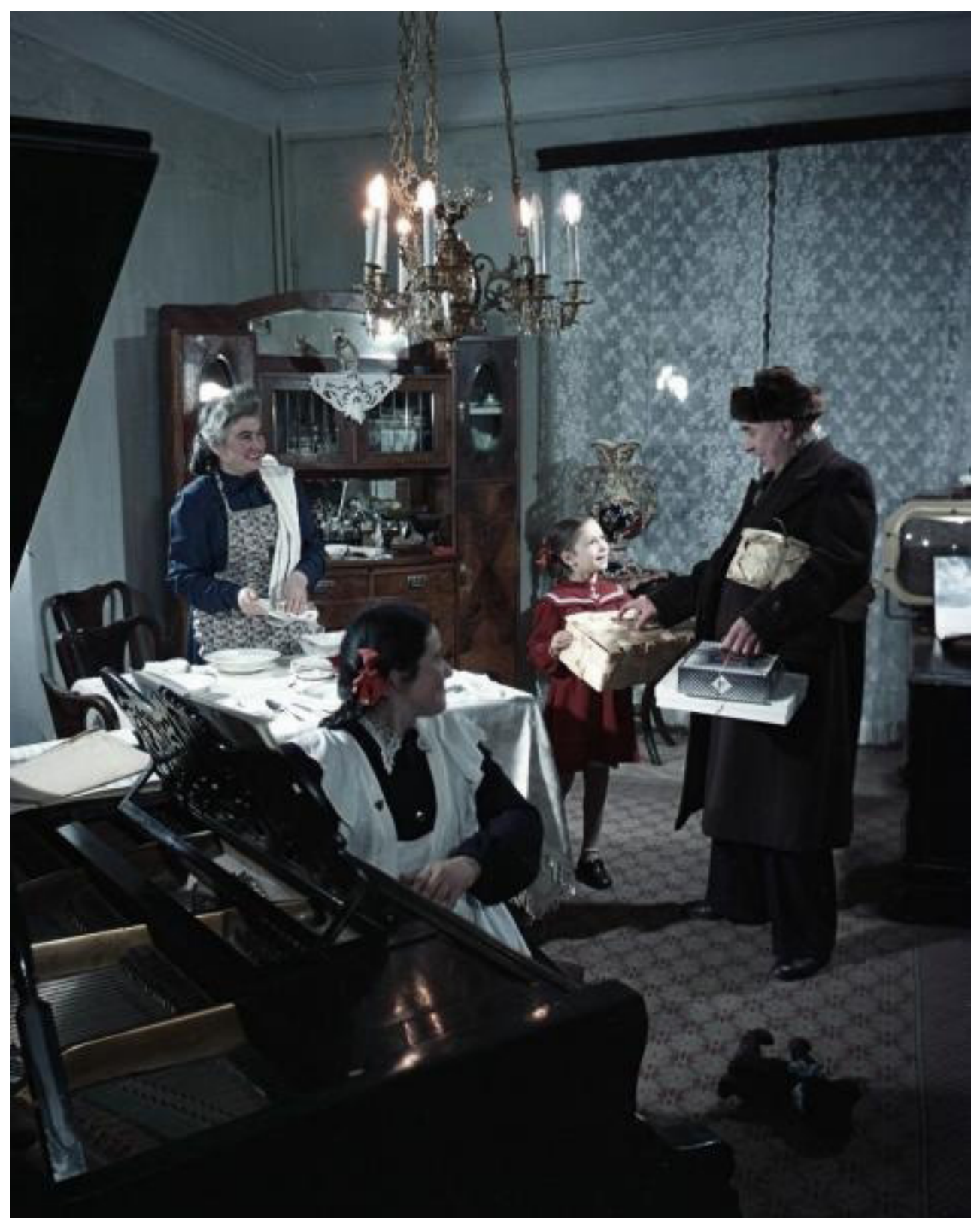

FIGURE 3 Commodity fetishism that kommunalka residents could only dream of (1954). Tarasevich, V. Retrieved from https://187011.selcdn.ru/thumbnails/photos/i/p/y/ipy53554e6481285_1024.jpg

partitions. Svetlana Boym (1994) recalls from her childhood in a kommunalka that "[partitions] mark the intersection of public and private spheres within the apartment" and "delineate [residents'] minimum privacy" (p. 146). Looking deeper into the objects themselves can show that the privacy these partitions provided might be the most fetishized commodity. Examining privacy through objects can demonstrate the widespread nature of commodity fetishism within Soviet mass-housing. Figure 3 shows residents with joyful expressions amidst objects and solid walls that give the interior a sense of privacy. Commodity fetishism and the desire for privacy could be found throughout mass-housing from the objects themselves to their impacts on byt (Marx, 1979; Boym, 1994). Later in the 1960s thaw, the state attempted to revisit commodity fetishism. The state was interested in "correct, socialist, non-fetishistic relation[s] to commodities" (Reid, 2014, p. 99) as part of developing forms of more private mass-housing. Commodity fetishism may have caused residents to use objects as ways of gaining coveted privacy in mass-housing. 


\section{Khrushchyovka Space Updates and Changing Objects}

Updates to mass-housing byt and material culture came under Khrushchev's thaw and shift away from Stalinism. Khrushchyovkas were developed as modern apartment blocks, meant to be mass-produced and prefabricated. The khrushchyovka gave residents a newer and less crowded modern socialist home (Reid, 2014). This new space also encouraged changes in material culture to move away from petit-bourgeois objects that dominated kommunalkas. The new khrushchyovka housing stock "was a gift, and [therefore]...imposed obligations on the [residents]" (Reid, 2014, p. 97). Framing the changes of byt as a gift allowed the khrushchyovka subtler ways of creating change as opposed to the early Soviets. This giffing set the tone for changes in byt and material culture of khrushchyovkas.
The updates in byt brought changes and new aspects to material culture. Standardized and simplified objects with Constructivist designs such as 'combination furniture' came following the emergence of modern homes (Bowlt, 1980). Such furniture can be seen in figure 4 , with less details and made to fit more efficiently into the housing space. In contrast to the scarcity and Great Purges experienced under Stalin, the khrushchyovka offered residents "a complete fresh start" (Reid, 2014, p. 112). This was a delayed follow-up on the 1930's promise that "socialism would bring abundance" (Fitzpatrick, 1999 , p. 89) to byt through material culture. Beginning in the 1960s, mass-produced objects such as furniture, radios, televisions, cameras and electrical appliances began to enter the new khrushchyovkas (Buchli, 1999). The Red Corner was updated again to include the television (Boym, 1994). This new technology gave the state a more direct way of spreading and

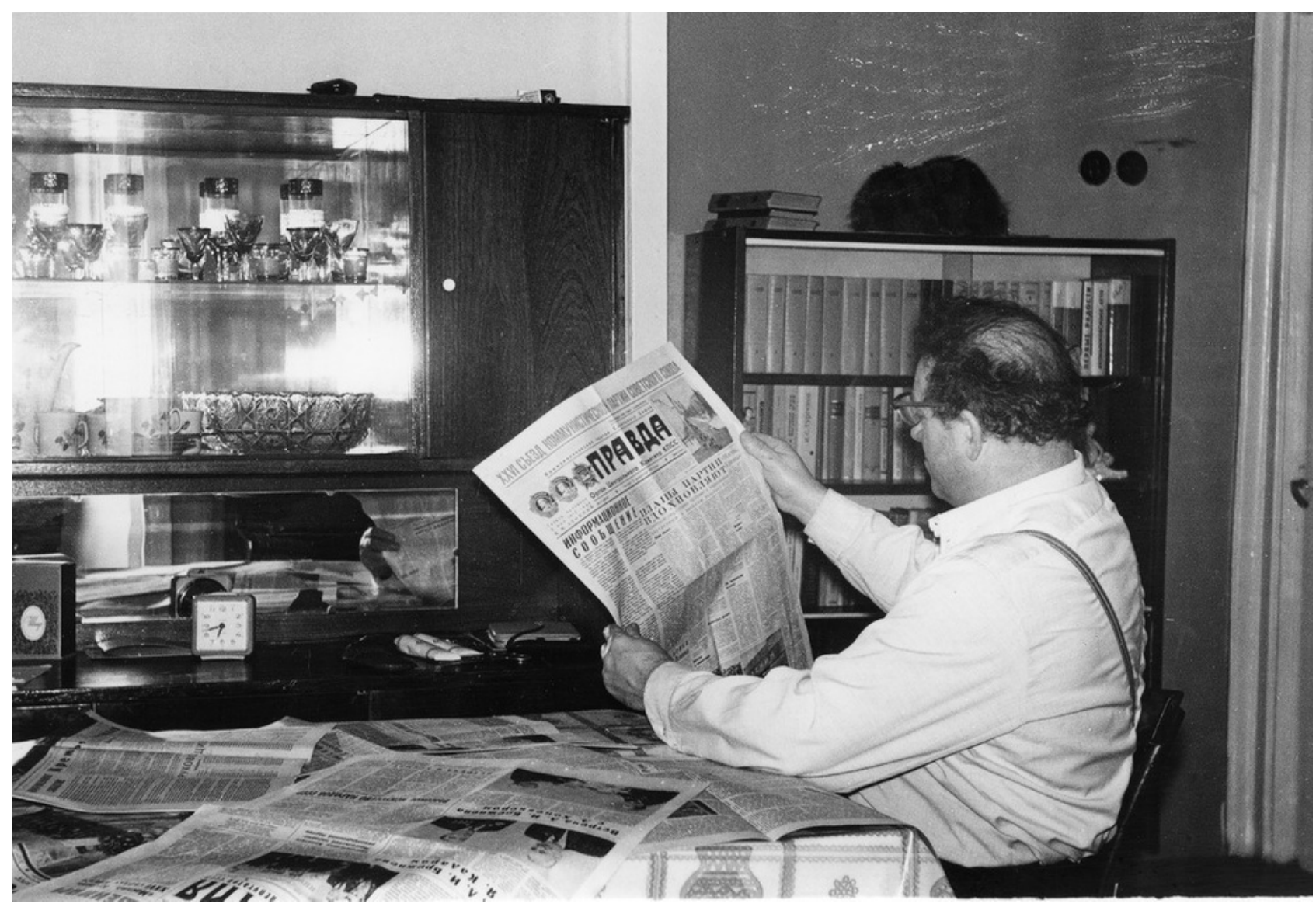

FIGURE 4 Resident with commode (1981). Afanasyev, S. Retrieved from https://187011.selcdn.ru/ thumbnails/photos/2017/10/23/du0qi55t8ht6l0aq_1024.jpg 


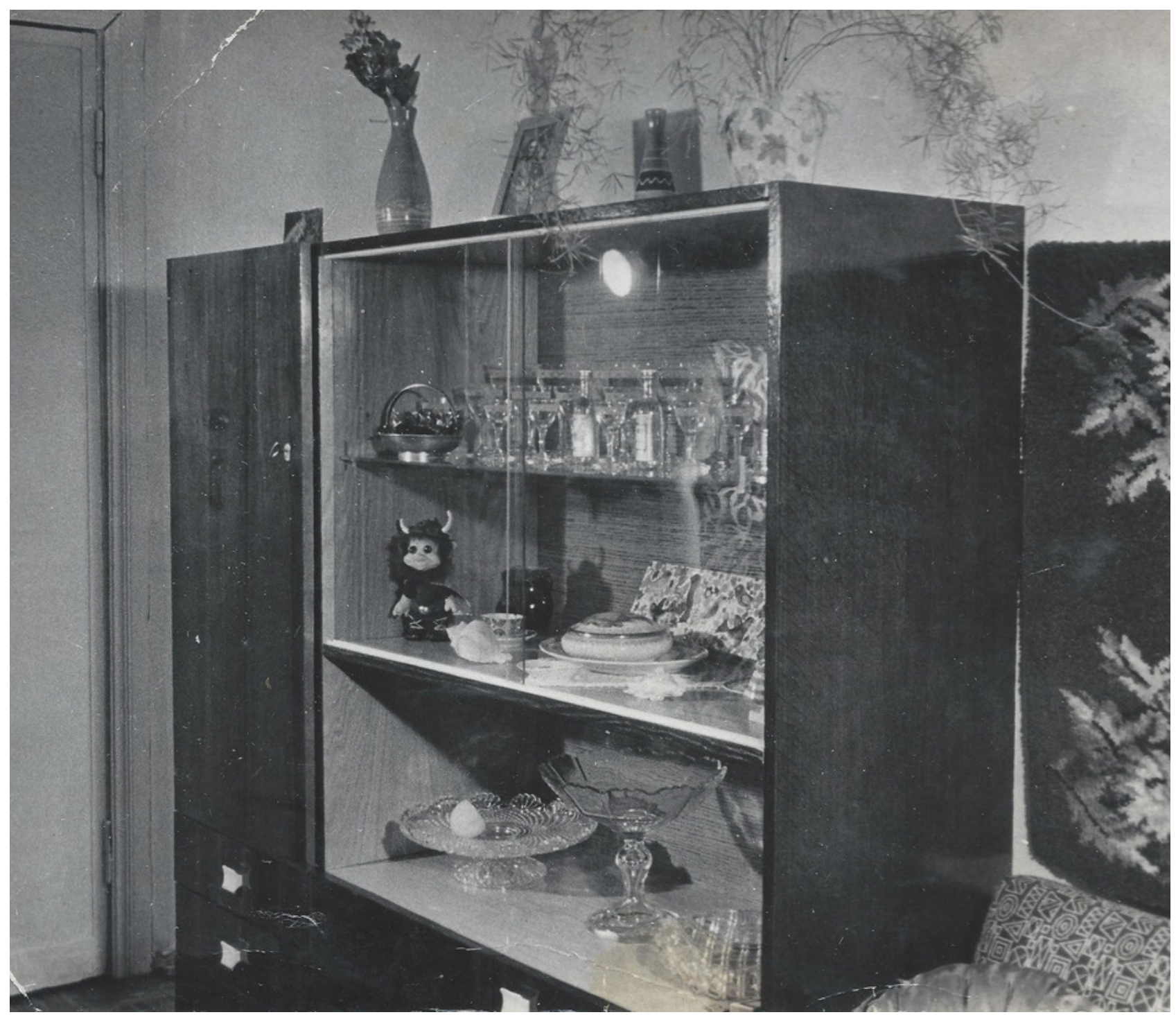

FIGURE 5 Commode with Troll Doll (1970). Retrieved from https://187011.selcdn.ru/thumbnails/ photos/2016/08/30/f3tnctzvokvf7atx_1024.jpg

displaying Soviet icons within the khrushchyovka. The commode was recommended by the state to be replaced with the Slavainskii Shkaf, a newer and narrower cabinet (Buchli, 1999). A key difference between the two pieces of furniture is that a Slavainskii Shkaf lacks any 'ornamental details and is considered to be less commodity fetishized than a commode (Boym, 1994). However, figures 4 and 5 show residents using this modern piece of furniture for essentially the same propose of displaying commodity fetishized objects. Similar to their role in the kommunalka, commodes and the newly adapted Slavainskii Shkaf continued to be expressions of individuality. Updates in mass-housing and material culture and continued to modernize byt.

\section{Khrushchyovka Residents' Relationships with the State and Objects}

Khrushchyovka residents' relationship with the state continued to be conflicting in terms of control of space and consumption of objects. Although the khrushchyovka offered privacy, control over the space remained a point of contention. The total security of the residents provided by khrushchyovka was exchanged for residents having "control over immediate satisfaction" (Buck-Morss, 2000, p. 205) which the state 
still held. This relationship created insecurity for residents who lacked control of the space, and looked to consumption of objects. In order to get the new, tasteful and modern objects residents were forced to "conform to the economic conditions of scarcity" (Chapman, 2013, p. 43). This left residents with few options of getting objects and allowed the state more control over the mass-housing interior. The conflict between the state and residents over control of byt as well as consuming material culture resulted in a somewhat dysfunctional relationship.

The khrushchyovka led residents to further develop their relationships with objects. Despite the shortages, there was a new "playful attitude toward fetishism and acquisitiveness" (Chapman, 2013, p. 39) of objects, meaning that residents could be now be more upfront and open with their commodity fetishism. In the context of shortages, residents took to "scarce items or even their remnants" (Chapman, 2013, p. 27) instead of unattainable new objects. This behavior shows a deep attachment to objects and preserving parts of the past. It might also explain the residents' continued attraction towards the commode. The khrushchyovka acted as a space for newer and more intensified commodity fetishized relationships with objects.

\section{Objects and Control over the Interior}

The objects and spaces within Soviet masshousing represented a push and pull in reconfiguring byt, in terms of individuality and time. Both the kommunalka and khrushchyovka were created by the state to dismantle privacy and in opposition residents used them to express individuality. Despite the state's ongoing efforts, residents still held onto and assembled a sense of individuality through objects and spaces within mass-housing. This is reflected by residents assembling "objects of trivial private utopias and of mass aesthetics" (Boym, 1994, p. 154) to create their own interiors. Figure 5 shows part of such a space, with a commode holding a decorated glassware set, artificial plants, and a Scandinavian troll doll. The troll doll, as a prized and commodity fetishized object from the West, gives its owner an individuality and an awareness for life outside the Soviet reality. The troll doll and other objects of the mass-housing interior also act as "souvenirs of privacy itself" (Boym, 1994, p. 159) which may have been the most fetishized commodity by residents and the state. The state's early efforts at creating a new byt were attempts to use mass-housing to "subvert individual subjectivity itself" (Santacose, 2014, p. 8) by taking control of the interior spaces and objects. Residents, in spite of shortages and scarcity, attempted to assert their own control over byt by turning the interiors into "spaces of excess" (Chapman, 2013 , p. 43) as seen through the commodes in figures 2, 3, 4 and 5. Individuality was a focus of the reconfiguration of byt and the interior.

The idea of time was another focus in the struggle over byt and material culture. The state dictated the housing of tomorrow and modern tastes in objects. On the other hand, residents held on to the past with "commemoration and preservation" (Boym, 1994, p. 150) in older and traditional housing or objects that they could acquire. Boym's (1994) metaphor of kommunalkas as "avant-garde matreska-dolls" (p.127) might best express the struggle over time. Boym's (1994) metaphor captures the Constructivist modern ideas and traditions of Red Corners and commodes occurring in close proximity, cramped beside each other in Soviet masshousing. This also expresses time as fractural with layers that can be scaled up and down, between the degrees of modernism and tradition. Within mass-housing, the past and future often existed side by side or enclosed by the layers of remaining privacy in byt and everyday life.

\section{Conclusion}

Soviet mass-housing was the site of many contradictions in everyday life, starting with the kommunalka where the commode and its petitbourgeois objects captured the focus of residents from the Red Corner. Within the kommunalka, the state focused on creating a new byt, while 
residents attempted to express individuality and privacy. The era of the khrushchyovka gave residents privacy but the state held control over the interior and the limited supply of massproduced objects. Within the khrushchyovka, commodity fetishism was embraced by residents through displaying new mass-produced and old objects. Throughout the time and spaces of Soviet mass housing commodity fetishism dominated the interior. The state's intentions of producing an expanded public realm inadvertently encouraged the residents to push back through commodity fetishism in seeking privacy and individuality. In the end, Soviet mass housing spaces and objects were the focus and products of both the changing and stagnant relationship between the state and residents.

\section{References}

Afanasyev, S. (1981). Viktor Ivanovich Arendar at home [Photograph].

Retrieved from https://187011.selcdn. $\mathrm{ru} /$ thumbnails/photos/2017/10/23/ duOqi55t8ht6lOaq_1024.jpg

Benjamin, W. (1986). Moscow diary. G. Smith (Ed.). Cambridge, MT: Harvard University Press.

Bowlt, J. E. (1980). The ideology of furniture: the Soviet chair in the 1920s. Soviet Union, 7(1/2), 138-156.

Boym, S. (1994). Common places: mythologies of everyday life in Russia. Cambridge, MT: Harvard University Press.

Buchli, V. (1999). An archaeology of socialism. Oxford, UK: Berg Publishers.

Buck-Morss, S. (2000). Dreamworld and catastrophe: the passing of mass utopia in East and West. Cambridge, MT: MIT Press.

Chapman, A. (2013). 'Trofeinost" and the phantasmagoria of everyday consumption in late Soviet culture. Studies in Slavic Cultures, 11, 24-49. Retrieved from http:// www2.pitt.edu/ slavic/sisc/SISC 11/ docs/chapman.pdf

Fitzpatrick, S. (1999). Everyday Stalinism: ordinary life in extraordinary times: Soviet Russia in the 1930s. New York, NY: Oxford University Press.
Marx, K. (1978). Wage labour and capital, the fetishism of commodities. In R. Tucker (Ed.), The Marx-Engels Reader (p. 319-329). New York, NY: W.W. Norton \& Company, Inc.

Reid, S. (2014). Makeshift modernity: DIY, craft and the virtuous homemaker in new Soviet housing of the 1960s. International Journal for History, Culture and Modernity, 2(2), 87-124. doi: 10.18352/hcm.465

Santacose, R. (2014). Designing the Bolshevik "interior": Walter Benjamin, 20th century Moscow and the question of Soviet demarcation. Hinge: A Journal of Contemporary Studies, 20, 4-18. Retrieved from https://ojs.library.dal.ca/hinge/ article/view/4383/4964

Savin, M. (1947). Meeting the new 1947 in the old Moscow apartment [Photograph]. Retrieved from https://187011. selcdn.ru/thumbnails/photos/8/I/ v/8lv52b30d9aa2884_1024.jpg

Tarasevich, V. (1954). The family of the engineer of the Moscow automobile plant named after Stalin, Konstantin Efimovich Malkov [Photograph]. Retrieved from https://187011.selcdn.ru/thumbnails / photos/i/p/y/ipy53554e6481285_1024. ipg

Unknown Author. (1939). Stakhanovets Magnitogorsk in his apartment for reading literature [Photograph]. Retrieved from https://187011.selcdn. ru/thumbnails/photos/w/7/e/ w7e52b33118a59d7_1024.jpg

Unknown Author. (1970). The Scandinavian Troll in Soviet Life [Photograph]. Retrieved from https://187011.selcdn. ru/thumbnails/photos/2016/08/30/ f3tnctzvokvf7atx_1024.jpg

Varga-Harris, C. (2015). Stories of house and home: Soviet apartment life during the Khrushchev years. Ithaca, NY: Cornell University Press. Retrieved from https:// www.academia.edu/30409932/ Christine_Varga-Harris._Stories_of_House_ and_Home_Soviet_Apartment_Life_during_ the_Khrushchev_Years._Ithaca_NY_ Cornell_University_Press_2015 